Marketing and Branding Research

WWW.CIKD.CA

\title{
Loyal Customers are Attached to Brands. Is this True? What is the Role of Customer Equity and Customer Trust?
}

\author{
Onamusi, Abiodun. $\mathbf{B}^{1^{*}}$, Ayo, Mofoluwake. $\mathbf{F}^{2}$ \\ ${ }^{1,2}$ Department of Management and Accounting Lead City University, Ibadan, Oyo State, Nigeria
}

\section{Keywords: \\ Brand attachment, Customer equity, Customer loyalty, Customer trust, Telecoms Industry}

\section{Received}

15 February 2021

Received in revised form

09 March 2021

Accepted

03 April 2021

*Correspondence:

abiodunonamusi@gmail.com

\begin{abstract}
Gaining customer loyalty is key to achieving repeated purchases that have ripple effects on sale revenue, market penetration, and profitability for firms. Can brand attachment guarantee customers' loyalty? Based on the assumptions of the theory of customer equity, the study evaluated the interactions of brand attachment, customer loyalty, customer equity, and customer loyalty, focusing on Nigeria's telecommunication industry. A survey-based approach to research with 1,035 active subscribers of five telecommunication companies in Nigeria was examined. Regression analysis was used to test the four-way hypotheses formulated in the study. Overall, the result showed that brand attachment had a positive and significant effect on customer loyalty. However, the link between brand attachment and customer loyalty was explained through customer trust to suggest a full mediation effect. Further analysis revealed that customer trust explained significant variation in customer equity. The study concluded that customer trust is a critical factor in achieving the benefit of brand attachment and customer equity. The study recommended that the management of the telecommunication companies in Nigeria invest significant resources to secure their customers' trust and adhere to the dimension of value, brand, and relationship equity given their concomitant effect on customer satisfaction and loyalty.
\end{abstract}

(C)CIKD Publishing

The telecoms industry in Nigeria grew from a meager .1\% contribution to GDP in 1999 to $10.3 \%$ in 2019 , this rise to prominence is reflected in the number of active subscribers, which grew from 2.3 million in 2002 to 187 million subscribers in 2019, and the concomitant penetration rate which rose from $1.9 \%$ to $96.8 \%$ given the years under review (National Communication Commission, (NCC), 2020). The need to communicate to foster socio-economic and political relationships provides the opportunity for telecommunication firms to be a going-concern. Likewise, the advent of a global digital economy meant telecommunication service providers have so much to offer to keep the socio-economic interaction worldwide. 
Despite this significant industry progress reported in Nigeria, the broadband penetration rate of 37.8\% in 2019 remained low compared to countries (South Africa \& Egypt) in Africa with fewer subscribers (NCC, 2020). Likewise, the service quality of the telecom firms becomes another reason to worry. For example, NCC (2018) documented increasing customer complaints about hidden data charges, poor internet connectivity even when the industry claimed a $4 \mathrm{~g}$ high-speed connectivity, inconsistent data deductions, and a general lack of trust. What guarantees profitable going-concern is when the firm consistently meets and exceeds customers' expectations via excellent service quality. A fall out of these customer complaints in Nigeria meant customer loyalty is a mirage in the telecoms industry, evidence by the rising number of subscribers porting from one network to the next in search of better service quality. NCC (2020) reported that within the first quarter of 2020, 3,701 MTN subscribers, 6,466 Airtel subscribers, 3,748 Globalcom's subscribers, and 1,756 9Mobile subscribers have ported out of each network, respectively.

Gaining customer loyalty is key to achieving repeated purchases which have a ripple effect on sale revenue, market penetration, and profitability (Bahri-Ammari, Haykel, \& Chtioui, 2016; Taghipourian \& Bakhsh, 2016). While studies have suggested firm-level competencies like innovation (Anning-Dorson, 2018), Customer relationship management (Itai \& Onamusi, 2020), new product development (Akroush \& Awwad, 2018), and marketing capabilities (Mu, Bao, Sekhon, Qi, \& Love, 2018) as a way to address customer loyalty, this study proposed brand attachment mechanism as an approach to achieving long-lasting customer loyalty.

Literature on brand attachment posited that it has a multiplier effect on customer satisfaction, loyalty, and increase sale turnover (Bahri-Ammari et al., 2016; Cheng, Luo, Yen, \& Yang, 2016; Danibrata, 2019; Levy \& Hino, 2016; Rashidi, Agheli, Tousizadeh, \& Zarinabad, 2020). However, the mechanism through which brand attachment affects customer loyalty remained unclear. Perhaps earning customer trust can serve as an underlining boundary condition through which brand attachment ability to influence customer loyalty can be explained. Likewise, we expect that to get the best of the customer lifetime value, trust becomes a critical factor. Given this discussion, this study examined the effect of brand attachment on customer loyalty. Also, we investigated the mediating effect of customer trust on the link between brand attachment and customer loyalty. Lastly, we assessed customer trust's effect on customer equity, focusing on telecommunication firms in Lagos State, Nigeria. It is important to note that the research questions asked in the study align with these above-identified objectives.

\section{Literature Review}

\section{Theory and Hypotheses Development}

The Theory of Consumer Equity (TCE) is considered appropriate to provide a theoretical explanation for the interaction of brand attachment, customer trust, customer equity, and customer loyalty. The TCE explains how an organization can obtain a lifetime value from potential and existing customers through proper customer relationship management (Hamdani, Herlianti, \& Maulani, 2019; Kolonio \& Soepeno, 2019; Yu \& Yuan, 2019). According to its proponents, the TCE employs three dimensions: value equity, relationship equity, and brand equity, to aid its relevance in customer loyalty-related studies (Asano, Cheng, Rhodes, \& Lok, 2019; Hamdani et al., 2019; Razzaq et al., 2019). First, value equity stressed that customers must get value for money. One can argue that customer satisfaction and loyalty is a function of customers achieving value for money each time a purchase is made. Second, brand equity meant the customer's perceived value of the organization exceeds its objective value. Hence, organizations that have developed goodwill 
and are known for excellent business practices over time are highly likely to have higher brand equity. Lastly, relationship equity stressed that the relationship between the customer and the organization might foster or destroy customer loyalty. Hence, developing a warm and robust relationship with new and existing customers is germane to achieving relationship equity. This discussion suggests that all TCE dimensions can explain the interactions between brand attachment, customer trust, customer equity, and customer loyalty.

\section{Brand Attachment and Customer Loyalty}

There has been consensus by various scholars that customer loyalty is germane for business profitability. According to Pasha and Waleed (2016), businesses cannot be sustainable without loyal customers. Many researchers have examined varying factors that can influence customer loyalty (Bahri-Ammari, Haykel, \& Chtioui, 2016; Itai \& Onamusi 2020; Rashidi et al., 2020; Pasha $\&$ Waleed, 2016). These factors range from a brand trust, customer satisfaction, perceived price, product appeal, and service quality. Though the concept of customer loyalty has been widely researched, it remains a relevant topic in both the academic and management field.

Taghipourian and Bakhsh (2016), in their study carried out within the banking sector, found that indicators of brand attachment (brand prominence and brand-self connection) have a significant positive effect on loyalty. Also focusing on the banking sector, Levy and Hino (2016) found a direct positive relationship between emotional attachment and loyalty. However, when customers are satisfied, this relationship becomes indirect but still positive. Similarly, Bahri-Ammari et al. (2016) found that brand attachment significantly explains consumer loyalty in luxury restaurants. According to the authors, this is so because brand attachment helps maintain relationships and repetitive purchase behavior. It has further been shown that when customers have an emotional attachment to a brand, they tend to have a positive perception and assessment of the brand, leading to customer citizenship behaviors and loyalty to the brand (Cheng et al., 2016).

Studying smartphone users in Jakarta, Indonesia, on how customer loyalty can be enhanced, Danibrata (2019) opined that to increase customer loyalty level, organizations must pay adequate attention to factors such as brand trust, product quality, and brand commitment. Besides, the author exerted that it is imperative for businesses to continually search for ways to improve customer loyalty which will, in turn, lead to greater profitability. Similarly, Rather, Tehseen, Itoo, and Parrey (2019) developed an integrated model of customer behavioral intention of loyalty indicators. Rather et al.'s (2019) model, focusing on the hospitality sector, was tested using data generated from customers lodging in several hotels within India. The findings indicate that brand trust, affective commitment, and customer satisfaction are direct customer loyalty predictors.

Rashidi et al. (2020) stated that for businesses to survive, they must have the ability to retain customers. This, according to the authors, can be achieved through a positive brand image, which creates a halo effect in the minds of customers, thereby influencing their behavior. Likewise, brand image has been shown to have a positive and significant effect on customer loyalty among Maybelline lipstick customers in Denpasar city (Wahyuningsih \& Sukaatmadja, 2020).

Studying mobile telecommunication companies in Ghana, Boateng, Kosiba, Adam, Ofori, and Okoe (2020) found that brand attachment types (identity and bonding based) have a significant relationship with brand loyalty. Brand attachment-satisfaction relationship positively influence customer continuance intention (Li \& Fang, 2019). Through brand affection, brand passion, and self-brand connection, experiential brands can build sustainable customer loyalty to their brand (Mostafa \& Kasamani, 2020). 


\section{Mediating Effect of Customer Trust}

Trust has been shown to have a significant positive impact on purchase behavior (Kumar, 2019). Also, a study has proven that trust mediates communication, perceived quality, and purchase behavior relationship (Al-Ekam, 2020). Brand experiences and associations enhance brand loyalty through a trustful relationship (Abdel, Naggar, \& Bendary, 2017). Similarly, Ratnasari, Arief, Hamsal, and Furinto (2019), in their study carried out in Indonesia, found that trust has a significant positive mediating effect on customer delight and loyalty in online shopping relationships.

Focusing on British and Spanish retail customers, Frasquet, Descals, and Ruiz-Molina (2017), in their study, found that brand trust has a significant and positive influence on both offline and online loyalty. Also, it was established that brand trust positively influences brand attachment and loyalty. Hoang (2019) highlights customer trust's role as a significant mediator in the relationship between customer dialogue and customer loyalty. Hwang, Baloglu, and Tanford (2019), in their study, opined that through trust and perceived fairness, hospitality marketers could develop sustainable brand attachment and grow share-of-wallet, thereby leading to increased profitability. According to Bhat, Darzi, and Parrey (2018), there is a significant impact of customer trust on loyalty. Also, there is a partial mediating effect of trust on the influence of satisfaction and knowledge on loyalty. Employee empathy has a significant indirect influence on service loyalty through trust. Also, conducting a mediation analysis, the researchers found that the paths of employee empathy to trust and then satisfaction is significant, indicating the mediating role of trust (Bahadur, Khan, Ali, \& Usman, 2020).

Customer experience has a significant positive effect on emotional brand attachment and customer trust, leading to a significant positive effect on customer loyalty (Sari \& Wijaya, 2019). This is similar to Sari and Yasa's (2019) findings, who concluded that customer trust has a mediating effect on the relationship between corporate image and customer loyalty. Examining the effect of brand trust on customer loyalty, Adewale and Bamidele (2016), in their study of telecoms subscribers in Nigeria, found that brand trust has a significant positive effect on customer loyalty. This is similar to the findings of Pasha and Waleed (2016), who found a significant positive effect of brand trust on loyalty in the Pakistani banking sector.

\section{Customer Trust and Customer Equity}

Trust is a crucial aspect of a business relationship, and the extent of its existence indicates the strength of a relationship (Asano et al., 2019). The importance of customer equity cannot be overestimated in the field and practice of marketing. For organizations to improve customer equity (value and relationship equity), they must develop strategies and programs to make customers trust the brand and feel they have a good relationship with the organization (Hamdani et al., 2019). According to Razzaq et al. (2019), drivers of emotions and equity are critical in-service encounters. The authors found that trust and emotions play a vital role with Chinese bank customers. However, Asano et al. (2019) found trust negatively relates to customer equity drivers.

$\mathrm{Yu}$ and Yuan (2019) found a direct influence of brand experiences on brand trust, brand attachment, and customer equity. Also, brand equity was found to have a positive effect on customer lifetime value. Chen et al. (2016) examined the impact of different contact points' experiences. Of the various brand experiences analyzed, product usage has the most influence on customer equity. Kumar's (2019) study of selected dairy in Chennai found that brand trust strongly affects customer satisfaction and loyalty. The authors proposed that business managers should always consider brand trust as the foundation to building customer satisfaction, leading to loyalty. 
For a long-term business relationship, brand trust is the dominant predictor. When customers trust a brand, long-term loyalty is likely to follow (Mabkhot, Shaari, \& Salleh, 2017).

With a focus on Islamic banking relationships, Tabrani, Amin, and Nizam (2018) investigated the role of trust in improving customer loyalty. While previous studies reviewed indicated a significant positive effect of trust on loyalty, these authors found that trust has no significant relationship with customer loyalty. They, however, showed that trust could significantly influence customer commitment and intimacy. Similarly, Kolonio and Soepeno (2019) found that brand trust does not significantly affect consumer loyalty. Furthermore, in their study on Balikpapan Hospital, Pertamina; Wulur, Militina, and Achmad (2020) found that brand trust positively affects customer loyalty. This effect is, however, not significant. The conceptual model in Figure 1 represents the interactions between brand attachment, customer trust, customer equity, and customer loyalty.

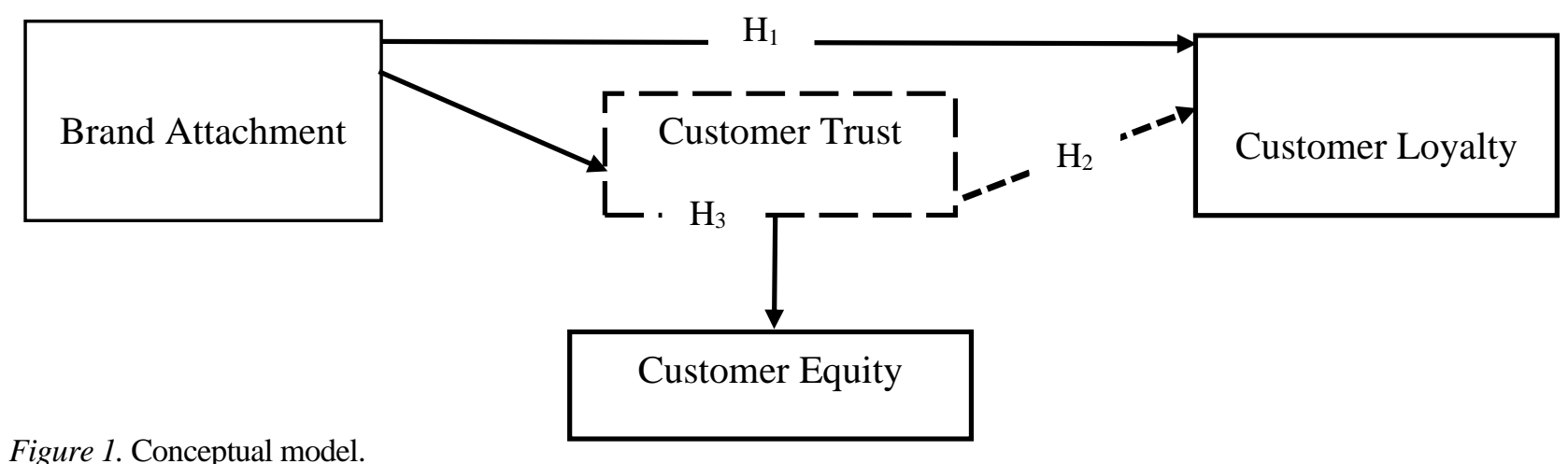

Figure 1. Conceptual model.

The resulting hypotheses are:

$\mathbf{H}_{1}$ : Brand attachment will have a positive effect on customer loyalty.

$\mathbf{H}_{2}$ : Customer trustfully mediates the association between brand attachment and customer loyalty.

H3: The effect customer trust has on customer equity will be positive and significant.

\section{Method}

\section{The Study Context and Population}

The interaction of brand attachment, customer trust, customer equity, and customer loyalty was examined within Nigeria's telecommunication industry. We considered the telecoms firms' customers, including MTN, Global communication, Airtel, Nine Mobile, and Smile Nigeria, because of this study's objective. More so, the discussion variable suggests using customers as the unit of analysis and ensuring collecting data from the appropriate source. The population of the study is 180 million active subscribers (customers) of telecoms firms under investigation.

\section{Sampling, Data collection, and Variable Measurement}

We sampled 1,036 customers of the telecom firms in Lagos, Ibadan, Abeokuta, Abuja, Kano, Kastina, Aba, and Port Harcourt using the snowball sampling technique during the inter-State lockdown in Nigeria. The customers sampled are those who have smartphones and could access the questionnaire from their smartphones. Of the 1,036 respondents, $43.9 \%$ were customers of MTN, 30.3\% were customers of Airtel, 21.9\% patronize Globalcom, and 3.9\% were customers of Nine mobile Nigeria. The snowballing technique became appropriate given that citizens were not allowing strangers into their homes for fear of the coronavirus pandemic. The researchers also needed to protect themselves from the coronavirus. The snowballing approach allowed access to a 
respondent in each State who, after filling the questionnaire, sends the link to other potential respondents. The process continues till an appropriate response rate is achieved. These customers are a homogeneous group; thus, the customers in States not considered do not invalidate this study's outcomes. It is important to stress that data were collected from the sampled customers at a point in time.

This study adapted from existing literature (Park et al., 2010; Sun \& Lin, 2010; Zeithaml, Berry, \& Parasuraman, 1996) a 25-item questionnaire to substantiate the link between brand attachment, customer trust, customer equity, and customer loyalty. The adapted questionnaire had six-point Likerttype-scale response options ( $1=$ strongly disagree, and $6=$ Strongly agree $)$. We conform to prior empirical survey research by ensuring that all the items measuring each variable in the questionnaire were evaluated by professional and senior lecturers in the department of management and accounting Lead City University Ibadan to ensure they align with literature and are not vague statements for respondents.

This study was conducted during COVID-19 pandemic inter-State lockdowns in Nigeria, and this meant physical distribution of the questionnaire was not possible. Hence, via the Google form (see appendix for the Google form link), the electronic mail system, and WhatsApp platforms, the questionnaires were administered using snowballing sampling technique (as explained earlier). After five weeks, we received 1,036 responses, considered a large enough sample size to run data analysis on SPSS.

The measurement of variables in this study follows a similar approach found in related studies. In this study, the independent variables are brand attachment and customer trust, the mediating variable is customer trust, and the dependent variables are customer loyalty and customer equity. The brand attachment, which reflects the emotional connection between customers and a brand, is measured following the five items scale found in Park et al. (2010). Customer trust reflects the belief customers have in a company's ability to guaranty meeting their needs consistently. Customer trust is measured following a 6-item scale found in Sun and Lin (2010). Customer equity reflects the sum of a customer lifetime value attributable to a business. It was measured following ten items scale, which captures the dimension of value, brand, and relationship found in Harrigan, Evers, Miles, and Daly (2017). Customer loyalty reflects the propensity that a customer will repeat patronage of a company's products, and it is measured following five items scale found in Zeithaml et al. (1996). These scale items were adapted to suit this study's context and analyze the interaction between brand attachment, customer trust, customer equity, and customer loyalty.

\section{Data Analytical Technique}

Considering the effect relationship hypothesized in this study, we used regression analysis to test the study's hypotheses. First, the effect of brand attachment on customer loyalty was examined. Second, the effect of customer trust on brand attachment was analyzed. Third, customer trust's mediating effect on the association between brand attachment and customer loyalty was examined using multiple regression analysis. Lastly, via the simple regression analysis, the effect of customer trust on customer equity was examined.

\section{Analysis and Result Validity and Reliability Test}

We validated the instrument and likewise ensured that it is reliable given its usage in this study and aligned with practice; to achieve this, a validity test and internal consistency reliability test were 
conducted. First, factor loadings for each item representing each construct (brand attachment, customer equity, customer trust, and customer loyalty) were obtained through factor analysis. They were used to compute Average Variance Explained (AVE) and the Composite Reliability (CR). The varimax extraction method allows the extraction of factor loadings for each construct. More so, the factor loadings extracted were above the 0.7 thresholds for each item. Second, the instrument's internal consistency reliability was confirmed by examining the Cronbach's Alpha (CA) Coefficient for all the constructs. The composite reliability equally provided additional evidence of construct reliability. Also, to ensure that a Common Method Bias (CMB) does not exist to invalidate this study's result, Harman's single factor test was conducted. The result showed that the percentage of variance explained by a single factor is $45.73 \%$ (.45). By rule, Harman's single factor result of less than 50\% (.50) suggests that CMB that can invalidate the result of a study does not exist in the data set used. Table 1 presents the validity and reliability test results for the variables of this study. Table 1 result shows that brand attachment, customer equity, customer trust, and customer loyalty have AVE, CR, CA values above the acceptable threshold of .5, .7, and .7, respectively, which suggest that the instrument is valid and reliable for this study (Hair, Black, Babin, \& Anderson, 2010).

Table 1

Validity and Reliability Test for Measured Items

\begin{tabular}{rllll}
\hline S/N & Latent Variables & CA & CR & AVE \\
\hline 1. & Brand attachment & .60 & .84 & .67 \\
2. & Customer trust & .89 & .83 & .66 \\
3. & Customer equity & .85 & .90 & .64 \\
4. & Customer loyalty & .91 & .91 & .74 \\
\hline
\end{tabular}

Table 2 presents the descriptive and correlation statistics for all the variables of this study. The mean score shows that respondents, on average, agree with the questionnaire items addressing each variable and the Pearson Product moment correlation coefficient shows that a reasonably strong and positive relationship exists among the variables under study.

Table 2

Mean, Standard Deviation and Correlation for all Variables

\begin{tabular}{lccccc}
\hline Variable Name & Mean & SD & $\begin{array}{c}\text { Brand } \\
\text { attachment }\end{array}$ & $\begin{array}{c}\text { Customer trust } \\
\text { Customer equity } \\
\text { loyalty }\end{array}$ & .58 \\
Brand attachment & 3.50 & .96 & 1 & 1 & .64 \\
Customer trust & 4.01 & 1.21 & & .79 \\
Customer equity & 3.94 & 1.09 & & 1 \\
Customer loyalty & 4.38 & 1.32 & & .72 \\
\hline Correlation is significant at the .01 level (2-tailed).
\end{tabular}

Table 3 presents the regression analysis result of the hypotheses formulated in this study. In the first model, how brand attachment influenced customer loyalty was assessed. In the second model, customer trust effect on brand attachment was determined. Also, the third model investigated the interaction between brand attachment and customer trust on customer loyalty. In the last model, how customer trust affected customer equity was analyzed and reported below.

We conducted a simple regression in the first model, and the result showed that brand attachment explained $20 \%$ changes in customer loyalty $\left(\mathrm{R}^{2}=.20, p<.01\right)$. In comparison, the remaining $80 \%$ is attributable to factors outside this study. The resulting $\beta$ eta coefficient (.61) suggested that when brand attachment changes by one unit; it will have a .61 increase in customer loyalty. The observed t-statistic $(16.08)$ and the $p$-value $(p<.01)$ established that the effect is significant. The result of this first model 
aligns with Baron and Kenny's (1986) criteria in a mediation analysis, which emphasizes that the interaction between two variables (independent and dependent) must be significant.

Similar to model one, the simple regression result in the second model revealed that $33.7 \%$ of changes noticed in brand attachment is caused by customer trust $\left(\mathrm{R}^{2}=.337, p<.01\right)$ while $66.3 \%$ left is contingent on factors outside the scope of this study. The resulting $\beta$ eta coefficient (.46) suggested that when customer trust changes by one unit, it will have a .46 increase in brand attachment. The observed t-statistic $(22.93)$ and the $p$-value $(p<.01)$ suggested that the effect is significant. The result of the second model aligns with Baron and Kenny's (1986) second step criteria in a mediation analysis, which emphasizes that the interaction between customer trust and brand attachment must be significant.

We conducted multiple regression analysis to establish the mediation effect in this study in the third model. The result posited that $66 \%$ of changes observed in customer loyalty are accounted for by brand attachment and customer trust (Adj. $\left.\mathrm{R}^{2}=.66, p<.01\right)$. The observed $\beta$ eta coefficient $(-0.05)$ suggested that when brand attachment change by one unit, it will decrease customer loyalty by .05 . The observed t-statistic (-1.86) and the p-value (.06) established that the effect is insignificant. Conversely, the observed $\beta$ eta coefficient (.91) suggested that when customer trust increases by one unit, it will increase customer loyalty by .91. The observed t-statistic (38.27) and the $p$-value $(p<.01)$ established that the effect is significant.

Baron and Kenny (1986) suggested that where the result in model one $(\beta=.61, t=16.08, p<.01)$ becomes insignificant $(\beta=-.05, t=-1.86, p=.06)$ in third model as a result of the introduction of new predictor variable (customer trust) with significant relative effect $(\beta=.91, t=38.27, p<.01)$ a full mediation effect is achieved. In line with Baron and Kenny's (1986) three-step mediation analysis, our results in the three models suggested that we met all the conditions. Hence, we can confirm that customer trust fully mediates the brand attachment-customer loyalty linkage, and the mediating effect is significant.

Lastly, we conducted a regression analysis to determinant the effect of customer trust on customer equity. The result revealed that customer trust explained $63.4 \%$ variation experienced in customer equity $\left(\mathrm{R}^{2}=.63, p<.01\right)$. In contrast, the remaining $36.6 \%$ is accountable to factors outside this study. The resulting $\beta$ eta coefficient (.72) suggested that when customer trust changes by one unit, it will have .72 increases in customer equity. The observed t-statistic $(t=42.34)$ and the $p$-value $(p<.01)$ established that the influence is positive and significant

Table 3

Summary of Regression Analysis for the Interaction of Brand Attachment, Customer Trust, Customer Equity, and Customer Loyalty

\begin{tabular}{|c|c|c|c|c|c|c|c|c|}
\hline Model & $\beta$ & $t$ & $p$ & $R$ & $R^{2}$ & Adj. $\mathrm{R}^{2}$ & $\mathrm{~F}(\mathrm{df})$ & $\operatorname{ANOVA}(p)$ \\
\hline${ }^{1}$ (Constant) & 2.22 & 15.99 & .00 & $.44^{\mathrm{a}}$ & .20 & .19 & $258.76(1.10)$ & .00 \\
\hline Brand Attachment & .61 & 16.08 & .00 & & & & & \\
\hline 2 (Constant) & 1.66 & 19.78 & .00 & $.58^{\mathrm{a}}$ & .33 & .33 & $525.85(1.10)$ & .00 \\
\hline Customer Trust & .46 & 22.93 & .00 & & & & & \\
\hline${ }^{3}($ Constant $)$ & .90 & 9.43 & .00 & $.81^{\mathrm{a}}$ & .66 & .66 & $1045.07(2.10)$ & .00 \\
\hline Brand Attachment & -.05 & -1.86 & .06 & & & & & \\
\hline Customer Trust & .916 & 38.27 & .00 & & & & & \\
\hline${ }^{4}($ Constant $)$ & 1.05 & 14.79 & .00 & $.79^{\mathrm{a}}$ & .63 & .63 & $1793.18(1.10)$ & 0.00 \\
\hline Customer Trust & .720 & 42.34 & .00 & & & & & \\
\hline
\end{tabular}




\section{Discussion and Conclusion}

The study assessed the effect of brand attachment on customer loyalty. It also investigated the indirect effect of customer trust on the association between brand attachment and customer loyalty. Lastly, the influence of customer trust on customer equity was examined. The result of this study confirms the hypotheses developed hence provides relevant implications for theory and practice. Loyal customer means repeated purchase which guarantees the going concern status of a business. In other ways, loyal customers tend to engage in non-paid advertisement campaigns through wordof-mouth to prospecting customers hence helping firms reduce costs attributed to advert expenditure. In the event of negative publicity, studies have found loyal customers to overlook this negative press and continue their patronage with the business. We have explored the relevance of brand attachment, customer trust and explained how customer equity could be influenced.

Brand attachment is a function of the level of trust customers have in a brand achieved after a sustained value, brand, and relationship equity. Likewise, customer trust over time creates the opportunity for companies to reap customer lifetime value (customer equity). When customers believe in a company's ability to guarantee their needs consistently, the sum of the customers' lifetime value attributable to the company will be enhanced. Hence, telecom companies' management in Nigeria has so much benefit from ensuring that they earn their subscribers' trust and conduct business to guarantee that customers enjoy value, brand, and relationship equity. This approach to customer management can secure a competitive advantage for companies as against others who do not.

This study's findings found support in prior empirical studies (Bahri-Ammari et al., 2016; Boateng et al., 2020; Li \& Fang, 2019; Taghipourian \& Bakhsh, 2016), which found brand attachment customer loyalty link to be positive and significant. More so, that the link is fully mediated by customer trust (Abdel et al., 2017; Bahadur et al., 2020; Frasquet et al., 2017; Hwang et al., 2019) and that customer trust had a significant effect on customer equity (Hamdani et al., 2019; Yu \& Yuan, 2019). The study concluded that customer trust is a critical factor in achieving the benefit of brand attachment and customer equity. The study recommended that the management of the telecommunication companies in Nigeria invest significant resources to secure their customers' trust and adhering to the dimension of value, brand, and relationship equity given their concomitant effect on customer satisfaction and loyalty.

We added to recent empirical studies on the interaction of brand attachment, customer trust, customer equity, and customer loyalty and situated the study within Nigeria's telecommunication industry. Although the link between brand attachment and customer loyalty has been established in previous studies, this study's findings confirmed the link and pushed for an explanation of how the link can be explained; this is critical in understanding how companies can achieve business sustainability through customer loyalty. We also found relevance for the TCE to buttress the findings of this study. The TCE explains how companies can acquire lifetime value from potential and existing customers through proper customer relationship management. This was considered the basis for hypothesizing that the dimensions of TCE, value, relationship, and brand equity will explain the interaction between brand attachment, customer trust, customer equity, and customer loyalty. By this study's outcome, we substantiated the hypotheses formulated and provided additional support for the assumption of the TCE within the telecoms industry in Nigeria. 


\section{References}

Abdel, R., Naggar, A., \& Bendary, N. (2017). The impact of experience and brand trust on brand considering the mediating effect of brand equity dimensions, an empirical study on mobile operator subscribers in Egypt. The Business and Management Review, $9(2), 16-25$.

Adewale, A. A., \& Bamidele, A. A. (2016). The relationship between brand trust and customer loyalty: The moderating impact of demographic characteristics. International Journal of Marketing Practices, 3(1), 1-23.

Akroush, M. N., \& Awwad, A. S. (2018). Enablers of NPD financial performance. International Journal of Quality \& Reliability Management, 35(1), 163-186.

Al-Ekam, J. M. (2020). The mediating effect of brand trust on the influence of communication, price and product quality on consumer purchase behavior in a less developed country. Malaysian Management Journal, 20, 87-97.

Anning-Dorson, T. (2018). Innovation and competitive advantage creation. International Marketing Review, 35(4), 580-600.

Asano, G., Cheng, T. V., Rhodes, J., \& Lok, P. (2019). The influence of online reviews and brand trust and customer equity: consumer equity. Journal of Electronic Commerce in Organizations, 17(4), 30-43.

Bahadur, W., Khan, A. N., Ali, A., \& Usman, M. (2020). Investigating the effect of employee empathy on service loyalty: The mediating role of trust in and satisfaction with a service employee. Journal of Relationship Marketing, 19(3), 229-252.

Bahri-Ammari, N., Haykel, V. N., \& Chtioui, K. J. (2016). The effects of brand attachment on behavioral loyalty in the luxury restaurant sector. International Journal of Contemporary Hospitality Management, 28(3), 559-585.

Baron, R. M., \& Kenny, D. A. (1986). The moderator-mediator variable distinction in social psychological research: Conceptual, strategic, and statistical considerations. Journal of Personality and Social Psychology, 51(6), 1173-1182.

Bhat, S. A., Darzi, M. A., \& Parrey, S. H. (2018). Antecedents of customer loyalty in banking sector: A mediational study. The Journal for Decision Makers, 43(2) 92-105.

Boateng, H., Kosiba, J. P., Adam, D. R., Ofori, K. S., \& Okoe, A. F. (2020). Examining brand loyalty from an attachment theory perspective. Marketing Intelligence and Planning, 38(4), 479-494.

Chen, A. C. H., Chen, S. K., \& Ma, C. L. (2016). Brand experience and customer equity prediction. Advances in Business and Management Forecasting, 11, 19-38.

Cheng, J. C., Luo, S. J., Yen, C. H., \& Yang, Y. F. (2016). Brand attachment and customer citizenship behaviors. The Service Industries Journal, 36(7-8), 263-277.

Danibrata, A. (2019). Enhancing customer loyalty through product quality, brand commitment, and brand trust. Southeast Asia Journal of Contemporary Business, Economics \& Law, 20(2), 27-31.

Frasquet, M., Descals, A. M., \& Ruiz-Molina, M. E. (2017). Understanding loyalty in multichannel retailing: The role of brand trust and brand attachment. International Journal of Retail \& Distribution Management, 45(6), 608-625. https//doi.org/10.1108/IJRDM-07-2016-0118

Hair, J. F., Black, W. C., Babin, B. J., \& Anderson, R. E. (2010). Multivariate data analysis: A global perspective (7th ed.). Upper Saddle River, NJ: Prentice-Hall.

Harrigan, P., Evers, U., Miles, M., \& Daly, T. (2017). Customer engagement with tourism social media brands. Tourism Management, 59, 597-609.

Hamdani, N. A., Herlianti, A. O., \& Maulani, G. A. (2019). Customer equity in the marketplace. International Journal of Innovation, Creativity and Change, 8(3).

Hoang, D. P. (2019). The central role of customer dialogue and trust in gaining bank loyalty: An extended SWICS model. International Journal of Bank Marketing, 37(3), 711-729. https://doi.org/10.1108/JJBM-03-2018-0069

Hwang, E., Baloglu, S., \& Tanford, S. (2019). Building loyalty through reward programs: The influence of perceptions of fairness and brand attachment. International Journal of Hospitality Management, 76, 19-28.

Itai, M. M., \& Onamusi, A. B. (2020). Customer relationship management and customer loyalty: An empirical study of selected deposit money banks in Lagos State, Nigeria. IAR Journal of Business Management, 1(4), 406-412.

Kolonio, J., \& Soepeno, D. (2019). Effects of service quality, trust, and consumer satisfaction on consumer loyalty at Cv. Facilities of marine fiberglass, 7(1), 831-840.

Kumar, D. S. (2019). Impact of perceived quality, brand image and brand trust on customer satisfaction and loyalty: A study of selected dairy products in Chennai. Journal of the Gujarat Research Society, 21(14), 1073-1083.

Levy, S., \& Hino, H. (2016). Emotional brand attachment: a factor in customer-bank relationships. International Journal of Bank Marketing, 34(2), 136-150.

Li, C., \& Fang, Y. (2019). Predicting continuance intention toward mobile branded apps through satisfaction and attachment. Telematics and Informatics, 43, 101248. https://doi.org/10.1016/j.tele.2019.101248 
Mabkhot, H. A., Shaari, H., \& Salleh, S. M. (2017). The influence of brand image and brand personality on brand loyalty, mediating by brand trust: An empirical study. Jurnal Pengurusan (UKM Journal of Management), 50, 71-82.

Mostafa, R. B., \& Kasamani, T. (2020). Brand experience and brand loyalty: Is it a matter of emotions? Asia Pacific Journal of Marketing and Logistics, ahead-of-print(ahead-of-print). https://doi.org/10.1108/apjml-11-2019-0669

Mu, J., Bao, Y., Sekhon, T., Qi, J., \& Love, E. (2018). Outside-in marketing capability and firm performance. Industrial Marketing Management, 75(6), 37-54.

NCC. (2018). Telecommunications industry report. Retrieved from NCC website: http://www.ncc.gov.ng

NCC. (2020). The Nigeria telecommunications industry report: A transformative past, resilient future. Retrieved from NCC website: http://www.ncc.ng

Park, C. W., MacInnis, D. J., Priester, J., Eisingerich, A. B., \& Iacobucci, D. (2010). Brand_attachment and brand attitude strength: Conceptual and empirical differentiation of two critical brand equity drivers. Journal of Marketing, 74(6), 1-17.

Pasha, A., \& Waleed, A. (2016). Factors affecting customer loyalty in banking sector of Punjab, Pakistan. Paradigms: A Research Journal of Commerce, Economics, and Social Sciences, 10(2), 43-52.

Rashidi, H., Agheli, M., Tousizadeh, S., \& Mokhavarpour Zarinabad, R. (2020). Factors affecting customer loyalty with the mediating role of emotional satisfaction and brand trust; Case study: Pasargad Insurance customers in Ilam Province. Journal of International Marketing Modeling, 1(1), 31-44.

Rather, R. A., Tehseen, S., Itoo, M. H., \& Parrey, S. H. (2019). Customer brand identification, affective commitment, customer satisfaction, and brand trust as antecedents of customer behavioral intention of loyalty: An empirical study in the hospitality sector. Journal of Global Scholars of Marketing Science, 29(2), 196-217.

Ratnasari, E. D., Arief, M., Hamsal, M., \& Furinto, A. (2019). The mediating effect of electronic trust in the effect of customer delight to e-loyalty, International Journal of Mechanical Engineering and Technology, 10(5), 207-213.

Razzaq, Z., Razzaq, A., Yousaf, S., Akram, U., \& Hong, Z. (2019). The impact of customer equity drivers on loyalty intentions among Chinese banking customers: The moderating role of emotions. Asia Pacific Journal of Marketing and Logistics, https://doi.org/10.1108/APJML-10-2017-0243

Sari, A. R. P., \& Yasa, N. K. (2019). The role of customer trust as a mediation on the effect of corporate images and price fairness to customer loyalty. Journal of Business Management and Economic Research, 3(8), 1-17.

Sari, E. K., \& Wijaya, S. (2019). The role of emotional brand attachment and customer trust in enhancing customer experience's effect on customer loyalty towards beauty clinics in Surabaya. Petra International Journal of Business Studies, 2(1), 18-26.

Sun, P. C., \& Lin, C. M. (2010). Building customer trust and loyalty: An empirical study in a retailing context. Service Industries Journal, 30(9), 1439-1455.

Tabrani, M., Amin, M., \& Nizam, A. (2018). Trust, commitment, customer intimacy and customer loyalty in Islamic banking relationships. International Journal of Bank Marketing, 36(5), 823-848.

Taghipourian, M. J., \& Bakhsh, M. M. (2016). Brand attachment on service loyalty in banking sector. International Journal of Marketing Studies, 8(5), 146-156.

Wahyuningsih, G. A. D., \& Sukaatmadja, I. P. G. (2020). The effect of brand image, product quality, and brand trust on Maybelline lipstick customer loyalty in Denpasar City. American Journal of Humanities and Social Sciences Research (AJHSSR), 4(1), 407-412.

Wulur, L. M., Militina, T., \& Achmad, G. N. (2020). Effect of service quality and brand trust on customer satisfaction and customer loyalty Pertamina hospital Balikpapan. International Journal of Economics, Business and Accounting Research (IJEBAR), 4(01),72-83.

Yu, X., \& Yuan, C. (2019). How consumers' brand experience in social media can improve brand perception and customer equity. Asia Pacific Journal of Marketing and Logistics, 31(5), 1233-1251. https://doi.org/10.1108/apjml-01-2018-0034

Zeithaml, V., Berry, L., \& Parasuraman, A. (1996). The behavioral consequences of service quality. Journal of Marketing, 60(2), $31-46$.

\section{Appendix}

Google form link for this study's questionnaire:

https://docs.google.com/forms/d/e/1FAlpQLSfBpJsvqmFrQHiTiPUIOklf-IxEBoZK1hdog0dyhzv1Tyl7TA/viewform 